\title{
Report
}

Strange Enlightenments: Flann O’Brien \& Modernism

John Hume Institute for Global Irish Studies, and the Centre for Modernism, The University of New South Wales, Sydney, Australia, 11 November 2011

\author{
Maebh Long \\ University of the South Pacific, Fiji
}

It is difficult to write a report on a Flann O'Brien conference without giving in to the temptation to present a thrilling new instalment of Cruiskeen Lawn. But, tempting as it is to leap boldly onto the bandwagon at a time when it actually might be both profitable and popular, pale imitations of wit cause more stomach upsets than the Brother's tonics could ever fix. And so, without flair, panache, or the blessing of Brother Barnabas - Sir Myles is at his country retreat and not accepting callers - my pen proffers a dry account of Sydney's contribution to the 2011 Flann O'Brien centenary conferences, held also in Vienna, Dublin, and Singapore. These symposia, together with the publications arising from them, reflect the growing recognition of the importance of Brian O'Nolan's texts as experimental literature, as Irish modernist works, and as major players in the current redefining and repositioning of modernism. 'Tis time to give the man his due, for his like will never be seen again.

The proceedings were opened by Rónán McDonald, director of the John Hume Institute for Global Irish Studies, and the first panel plunged, before breakfast was allowed to settle, into a rousing repast of sin, irony, lies, and nonsense. In 'Four More Sins, Potentially Deadly, by Flann O'Brien' Sean Pryor (UNSW) read The Third Policeman and At Swim-Two-Birds through Augustine, Dante, and ideas of original sin. Positing a dialectic between the mad scientist and the theologian, he spoke on themes of justice and injustice, and the relative sins of author, character, and reader. Stephen Abblitt (La Trobe University) then took to the floor and, in " Poor Jimmy Joyce" and the Ironic Modernism of The Dalkey Archive,' addressed the (undead) figure of Joyce in O'Nolan's last completed novel, tracing the paternal influence through Derrida. The third panellist - truth is always an odd number - John Attridge (UNSW) spoke on '“The real lie": Lying and Nonsense in Flann O'Brien.' Bringing us back to Augustine, this time we meet him as the man who first systematised - and condemned - the lie, 
and in particular the 'real lie,' that which is told simply for the pleasure of deceit. $\mathrm{O}^{\prime}$ Nolan was, we see, a real liar, delighting in false trails and fake identities.

In “'Yer nam is Jams O'Donnell!": Proper Names in An Béal Bocht,' Maebh Long (University of the South Pacific), opened a dialogue with Gaeilgeoir (minus the bicycle clips) Jonathan Ó Néill (Australian National University) and his paper 'Brian O'Nolan's Engagement with the Irish language.' Long read the legal and ontological implications of 'Jams O'Donnell' through Mill and Derrida, while Ó Néill's excellent translations and expositions of 'Teacht agus Imtheacht Sheáin Bhuidhe,' 'Dioghaltas ar Ghallaibh 'sa Bhliadhain 2032!,' and An Béal Bocht explored the notion that the 'crisis of representation' that $\mathrm{O}^{\prime}$ Nolan saw in the Irish language movement was a 'shock of the old' rather the 'make it new' of modernism. No (John) bull there, but an interesting counter-step to the prevailing one of modernism. Stefan Solomon's (UNSW) "“The outward accidents of illusion": O'Brien and the Theatrical,' drew an eager audience through O'Nolan's too often ignored plays - Thirst, Faustus Kelly, and Rhapsody in Stephen's Green: The Insect Play - and the dramatic qualities of his novels. While the student's manifesto in At Swim-Two-Birds declares that the novel's aping of realism makes it inferior to the play, Solomon argued that in O'Nolan's works the novel tends already to be (a) play, and thus cunningly avoids such demotion.

The postprandial slot saw digestion aided by the revolutions of bicycle wheels and spinning wheels. The third policeman, one might say, was a weaver, and while omnium might be a track cycling race, it also makes a fine pair of pants. Mark Byron's (University of Sydney) 'Modern Velocipedes' and Mark Steven's (University of Sydney) 'Hell Goes Round and Round: Flann O'Brien and the Modernist Bicycle' presented a double act of modernist bicycles careering through Cartesian Centaurs, Hugh Kenner, Samuel Beckett, Alfred Jarry, Filippo Tommaso Marinetti, and Walter Benjamin. Metaphysics becomes the revolutions of the velocipedal 'vicocyclometer' 1 - as Joyce put it in Finnegans Wake - though as we know, Myles himself was also a big fan of the train. The flapping skirts of the female cyclist then sped us on to Marie O'Mahony (University of Technology Sydney) and 'Futuristic Textile Technologies from the World of Science through the Writings of Flann O'Brien,' who linked the story-teller's book web to the careful mesh of a textile-maker's cloth.

Opening the final panel with 'The Calm-Sorcery of Chess: Flann O'Brien's Mathematical Modernism,' Baylee Brits (UNSW) counted through the twos and threes of At Swim-Two-Birds, while in 'No Unauthorised Boozing: Flann O'Brien and the Thirsting Youth,' Sam Dickson (University of Sydney) spoke of the thirsty scholar and the thirsty muse. Licensed premises indeed. In 'Flann O'Brien and the Risibility of Modern Life,' David Kelly (University of Sydney) found one or two more laughs than the cracked looking glass of the servant provides, focusing primarily on At Swim-Two- 
Birds. Finally, the round table led by Rónán McDonald saw Don Anderson (University of Sydney), Frances Devlin-Glass (Deakin University), John Kelly (Oxford University), and Julian Murphet (UNSW) speak on their early encounters with Flann and Myles, with notes on his conservatism in relation to Ireland and the Church, and some reflections on his feminism, or lack thereof.

The theme of this conference - Flann O'Brien and Modernism - while often tangentially addressed, reflected an important and continuing trend in the positioning of O'Nolan's works away from postmodernism and into (late) modernism. The step away from reading the ludic and intertexual dimensions of $\mathrm{O}^{\prime}$ Nolan's writings in terms of a contextless postmodern excessiveness does perhaps imply a somewhat reductive reading of postmodernism itself, but primarily facilitates a grounding and a positioning of O'Nolan's texts within the concerns of Irish and European modernism. Like Beckett's Murphy, O'Nolan's texts are 'a flux of forms, a perpetual coming together and falling asunder of forms ${ }^{2}$ in keeping with the texts of Joyce and Beckett, but also Brecht, Kafka, Pound, and Eliot. The movement between close textual analysis and theoretical exploration mirrored the growing trend of situating $\mathrm{O}^{\prime}$ Nolan within the canon of modernists who did not simply reflect the Zeitgeist, but who shaped an emerging nation and its literary creation/representation.

Finally, saturated with wise and wonderful anecdotes, the Flanneurs nonetheless gamefully found room for a pint of plain (or a bottle of wine) at the conference dinner. Many thanks to Rónán McDonald, Angela McLoughlin, and all at the Irish Studies in UNSW for such a stimulating day.

\section{Notes $\mathcal{E}$ references}

${ }^{1}$ James Joyce, Finnegans Wake (London: Penguin, 2000), 614.

2 Samuel Beckett, Murphy (New York: Grove Press, 1957), 112. 